\title{
The State of Jefferson Secession Movement “Keepin’ it Rural"
}

\author{
Henry C. Pullara ${ }^{1}$ and Maura Large ${ }^{1 \#}$ \\ ${ }^{1}$ Chadwick School, Palos Verdes Peninsula, CA, USA \\ "Advisor
}

\section{$\underline{\text { ABSTRACT }}$}

The current "State of Jefferson" movement is comprised of residents of a large rural region encompassing much of Northern California and Southern Oregon, where many inhabitants claim the right to statehood. Since its origins in 1941, the State of Jefferson remains an obscure movement for most scholars and is simply labeled a regionalist movement. While Jefferson possesses every factor of a secession movement, including economic and socio-political variables, the complexity of its ideology and identity has not been studied. This study aimed to answer the question, "How do those who claim to represent the State of Jefferson secession movement describe Jeffersonian identity and characterize the ideology of the movement? Under the guidance of framing theory, which states that "media, as well as individuals, frame issues according to their own views and values" (M'Bareck 9), a content analysis of ten Facebook accounts was used to provide unfiltered and authentic rhetoric espoused by the movement. Results indicated that the movement is driven by agrarianism, possesses conservative, yet libertarian values, and embraces an ideology of Jeffersonianism reflected in the name of the state. While remaining closely tied to their ideology, Jeffersonian self-identification is also rooted in the rural nature of the region in which they reside.

\section{Introduction}

Secession, "formal withdrawal from a central authority by a member unit" (Wood 110), is not a foreign concept to Americans. The United States originated from secessionist sentiment within the British Empire that culminated in the American Revolution. Since its independence, the U.S. has experienced internal and external secession movements, such as the Confederate States, and the secession of Texas from Mexico. Although Americans have experience with exchanges of territory between countries, completed territorial changes within U.S. states are harder to find. Attempts to secede internally are more frequent, and are often based on regionalism within states (Fox 185). The most significant example of this was West Virginia's split from Virginia in 1863, resulting in West Virginia's formation as a state. If certain circumstances arise such as potent regional identity combined with economic and political grievances, these conditions could spawn a secessionist movement. A current example is the case of the "State of Jefferson" (SOJ), a large rural region encompassing much of Northern California and Southern Oregon, where many residents claim the right to statehood. Although the movement originated in 1941 and is labeled as a purely regionalist movement, many factors have influenced the complexity of its ideology and its continued existence, which prompts the question: How do those who claim to represent the SOJ movement describe Jeffersonian identity and characterize the ideology of the movement? 


\section{History of Jefferson Secession Movement}

The roots of the movement are found in the Proclamation of Independence, created in 1941, which states "Jefferson is now in patriotic rebellion against the States of California and Oregon" (Davis 129). Although Jefferson is a secessionist movement, it retains a sense of American patriotism. Its secession is not for nationhood, but for the formation of a new state. Originally, the Jeffersonians utilized a frontier-themed aesthetic, calling for California to address their concerns or face secession. A primary concern was "impassable roads," a factor that inhibited economic growth (Davis 133), and a problem that still persists today. In the wake of the Pearl Harbor Attack, the Jeffersonians halted their quest for statehood to focus on the war effort. To historian W.N. Davis, Jr., Jefferson's movement of 1941 was the latest manifestation of the constant conflict dividing a state as large as California. He noted that "From the days of Spanish Rule, California has known many times the pull of local pressures working to get free of the larger political structure" (125). Though the original movement failed, issues that disproportionately affect rural Californians remain.

\section{Current Jefferson Secession Movement}

The current secession movement was revived in 2013, in response to the lack of political power that rural residents have within the State of California and that rural counties have vastly different needs than urban ones. Issues important to the Jeffersonians such as fire taxes and water rights are often overlooked in favor of issues important to the urban majority. According to Jefferson Public Radio, “on September 3, 2013, the Siskiyou County Board of Supervisors made national news when it voted four to one in favor of beginning the process of seceding from California to create the State of Jefferson by joining other southern Oregon and far northern California counties which would have a similar interest" (State of Jefferson). Following this declaration, twenty other Northern California counties declared independence. The population of the SOJ is 1.7 million, a small share of California's 40 million inhabitants (Menezes). Despite declarations of secession, these counties remain part of California. For Jefferson to become a state, it would need the consent of California's legislature and the U.S. Congress.

Jefferson has been widely covered by local media (Shulman; DeWolf) and national media (Michel; BransonPotts). Recently, a series of journal articles has presented theories about the movement. Historian Jeff Lalande calls the concept of Jefferson a "contested search for a true regional identity" (31), noting that Jeffersonians have "a sense of the region's specialness" (33). Lalande suggests that Jeffersonians have a fear of their region becoming “... less distinctive ... and more like everywhere else" (35). Additionally, he asserts that the "desire for increased self-determination" and "founding American mantra of 'No taxation without representation"'(36), are demonstrations of a desire for regional autonomy and return to traditional American values. Lalande "encourage(s) further inquiry into the broader State of Jefferson phenomenon" (16).

While Lalande focuses on cultural forces driving Jefferson, geographer Matthew Derrick, calls for further research, stating "the underlying [economic] circumstances driving the secessionists' complaints are certainly deserving of scholarly inquiry" (8) and believes that the idea of Jefferson as a "state of mind" or a bastion of "rugged individualism" (7) overlooks many of the actual problems facing the community. While Jefferson is often framed as a reaction to the progressivism of urban California, there are serious economic and political issues that disproportionately affect rural California. For example, the Jeffersonian economy, mostly based on timber, minerals, and fishing, has declined recently, increasing unemployment and poverty. In 2014, the counties of Jefferson had among the highest unemployment rates of rural counties in the United States, some in excess of twelve percent (6), contrasting with urban counties such as the Los Angeles-Long Beach Combined Statistical Area, which had an unemployment rate of 7.4 percent (Unemployment in Los Angeles).

In "The Elusive State of Jefferson," Jefferson scholar Peter Laufer recorded experiences meeting residents of the SOJ. Residents emphasized mistrust of state government and lack of representation within the state (106), in addition to lack of proper economic development (96). In a subsequent article, "All We Ask is to be Left Alone," 
Laufer presents similar grievances, stating that followers in California and Oregon want to "remedy by themselves the social and economic ills that they blame on the relative unimportance the rest of their states attaches to them and their territory" (17). In a radio interview, Laufer declares that secession "boils down more or less to a rural-urban divide. But, it also can be considered. . . a metaphor for the kinds of problems we see nationally: the stasis in Washington and the divisiveness" (Breaking Up is Hard to Do).

While the issues driving the SOJ are specific to the interests of the region, they fall within broader categories used to classify factors that further the success of secessionist movements. Historically, movements for regional autonomy have resulted in formation of new territories, and many are ongoing. To effectively understand Jefferson, it is necessary to review variables that influence separatist movements overseas and throughout history. Factors that drive a region to form its own country are similar to those that might result in the formation of a new state within a federal entity. Regional differences which drive separatism around the world include economic disparities, political grievances and cultural differences (Boyle and Englebert 2).

\section{Economic Factors}

Regional economic disparities are a primary factor influencing support for secession. Some movements are driven by a belief that a lackluster economy will be improved through independence, while prosperous regions seek to discard communities that are less economically-secure. Study of the South Sudanese secession movement, reveals a correlation between secession support and household economic situation: fifty-four percent of households with a secure economic situation supported secession, while forty-four percent opposed it (Braizat 12). Conversely, an empirical study covering sixty-one secession movements demonstrated that faster-growing economies can reduce support for revolutionary groups (MacCulloch and Pezzini 1). An empirical analysis of factors involved in challenges to the state found that groups who are economically aggrieved, excluded from power, and demanding total independence are more likely to resort to "irregular strategies" such as violence to achieve self-determination (Cunningham 302). Additionally, a cross-sectional analysis of data on civil conflicts between 1951-2004 revealed a higher chance of conflict in countries that are wealthy, but where many people are unable to access that wealth (Koubi 19). In the United States, economic disparities between rural Jefferson and urban California certainly influence support for Jefferson. Jefferson's weak economy when compared to that of California, combined with lack of political representation creates a climate favorable to secessionism. Similarly, Catalonia produces twenty percent of Spanish GDP, one-third of Spanish industrial output, and one-quarter of Spanish tax revenues but receives relatively little in return from the Spanish central government (Olomojobi and Omonye 141). Furthermore, Miley and Garvía found that forty-five percent of Catalans who supported independence did so for economic reasons (9), and studies of the current secessionist movement in Catalonia also found that economic issues play a role in support for secession, in addition to identity and partisanship concerns (Muñoz and Tormos 24). While the SOJ movement has been deeply impacted by economic factors, its identity, partisanship, and other sociopolitical issues are equally important in driving secession.

\section{Sociopolitical Factors}

Sociopolitical variables including political circumstances, elite interests (local political or economic leaders), internal and external recognition, nationalism, issues of identity, and partisanship may determine support for secession. Political circumstances can influence the success or failure of secessionist movements. For example, a 2019 article highlighted factors for the success of separatism in 2014 in the Ukrainian regions of Donetsk and Luhansk, citing differences in "public opinion," "economic exposure," and "elite preferences" as explanations why other regions of Ukraine never seceded (Buckholz 151).

While internal conditions are instrumental in the future of a secessionist movement, recognition by local, national, and global authorities can provide legitimacy for movements that possess de facto control over the territory 
they claim. For example, The Turkish Republic of Northern Cyprus's declaration of independence in 1983 was not followed by international recognition, in part because of pressure from the international community. James Ker-Lindsay notes, "it is certainly possible that the TRNC would have more recognition today had it not been for the quick and concerted effort by Britain to stop them" (446). In Jefferson, the federal government as well as California would have to officially recognize the SOJ, which does not possess de facto or de jure control over its claimed territory, thus undermining its legitimacy.

Recognition helps nationalist movements because it provides justification for their territorial ambitions, which ultimately reinforces nationalist identity. For example, Canada has a strong secessionist movement supporting the independence of Quebec and efforts by the Canadian government to create a pan-Canadian identity have increased Quebec nationalism (Guibernau 51), showing that pluralism and recognition of multiple regional identities may fuel greater identification with separatist movements, ultimately decreasing stability of a unified state. The Jeffersonian identity is similar to that of Quebec - it is based around a territory with cultural and geographical differences from the political entity of which it is considered a part. The reassertion of separate identities contributes to the secessionist movements in both cases. Identity is a powerful factor contributing to separatism. In Russia, perceived negative ethnic relations increased levels of separatism (Hagendoorn et al. 371), demonstrating that association with a group is a powerful influence in determining support for secession.

Association with a group influences support for a secessionist movement, and as people identify strongly with their political party, excessive partisanship can lead to a divisive system and ultimately spawn a secessionist movement. In Catalonia's secession from Spain, Torcal and Mota found that "the dynamics of sub-national party system competition, resulting from both the political positions adopted by non-state-wide parties and those of statewide parties, affect citizens' views and preferences by pulling them towards persistently divisive positions regarding the model of the state" (4). These variables and others, including a unique cultural identity, promote Catalonia's thriving separatist movement. Divisive partisanship encourages adoption of extreme views, which influences secession.

The multitude of economic and socio-political variables, which are common to many secessionist movements, both active and historical, can be understood within the context of the SOJ movement. In the United States and for the SOJ, these variables are primarily embodied within the "rural-urban divide."

\section{Regional Differences: Urban-Rural Divide in the United States}

For many years, rural-urban divisions have plagued America. The Civil War was fought between an industrializing North and an agrarian South. These divisions appear to be widening. The divide is "characterized by stark differences in political and social attitudes that appear to be fueled, at least in part, by diverging economic fortunes" (Accordino 217). Economically disadvantaged regions often experience less population growth, resulting in lesser representation, and consequently the inhabitants often resort to "irregular strategies" to achieve self-determination (Cunningham 292), as in the case of Jefferson.

Jeffersonian rhetoric is centered around opposition to a strong central government, as well as support for agrarianism, and fiscal and social conservatism. This rhetoric may be a reaction to urban America, whose inhabitants often see rural regions as "flyover states," peripheral entities, detached from the modern world. A recent study by the Pew Research Center found that two-thirds or more Americans in both urban and rural areas believe that the other side doesn't understand their problems, with majorities in both regions believing that the other has a negative view of them (Parker et al.). The urban-rural divide is widespread across the country, and California's experience with Jefferson's attempt at secession shows what could happen on a national scale if rural areas continue to lose power due to a relative decrease in population. A lack of population ultimately translates into a lack of representation in the U.S. House of Representatives, because the number of seats in the U.S. House allocated to states is based upon population. As the rural states' populations stagnate, their representation will continue to decline. The lack of representation is an important issue for rural residents, and has influenced their vote for the party that claims to put rural interests at the forefront of its campaign. In the 2020 Presidential Election, Joe Biden carried major cities, while rural areas (SOJ 
included) voted for Donald Trump (McKee). While Jefferson has been pursuing self-determination for decades, this growing division can be increasingly seen on a national level. A legislator in Mississippi recently called for secession from the Union in response to President Joe Biden's victory in 2020 (Armus). The urban-rural divide will continue to impact political discourse. Future national issues are illustrated on a regional level with Jefferson's movement to gain independence from California. Exclusion from economic and political power, lack of political recognition on a regional and statewide level, and absence of interest in rural issues by the urban population, have ultimately led Jeffersonians to push for statehood, and these growing sentiments can be seen on a larger scale. Understanding the nature of the SOJ and causes of its movement is necessary to properly address conflict that will emerge as rural areas continue to lose political relevance both regionally and nationally.

As urban-rural divisions influence political initiatives, it is alarming that such movements as the SOJ lack scholarly investigation, as Jefferson represents what could happen if the rest of the nation follows California's political pathway. Additionally the SOJ possesses driving factors that are present in other secessionist movements, yet remains relatively under-researched. Although the movement is being covered by mainstream news outlets, scholars have not fully identified the complexities that make up Jefferson's ideology, identity, and foundations beyond its label as a regional rural movement. What might hinder scholars investigating this movement is its relative obscurity due to the presence of outside groups within the movement, bringing with them their own interests and priorities, as well as the inherent diversity of those who associate themselves with the movement. In order to properly understand the nature of this movement, one must sift through a multitude of groups, with different ideologies and priorities, that share support for the creation of Jefferson. Due to the extensive diversity of perspectives within the movement, a further examination of the content directly produced by the movement and its members, as opposed to secondary sources through which most people encounter Jefferson, should indicate the most important issues for citizens of the proposed state, and unveil the essence of Jeffersonian ideology and identity. In the midst of the resurgence of Jefferson, the growing divide between rural regions and their urban counterparts, and the lack of scholarly exploration into the ideology and identity behind Jefferson, it seems more timely than ever to investigate and answer the question: How do those who claim to represent the State of Jefferson movement describe Jeffersonian identity and characterize the ideology of the movement?

\section{Methodology}

Case studies are analyses of persons, groups, events, policies, institutions or other systems that are studied holistically using in-depth and detailed examination within a real-world context. This research method allows for natural observations of individuals, groups, and entities across multiple time periods and within the time frame currently being studied. As a relatively small regional group within California, an in-depth investigation into this movement within its context will provide insight into the identity and ideology of the SOJ movement. Natural observation enables accurate data collection without the researcher influencing the attitudes and behaviors of those being studied. As a widespread regional movement, direct observation of the SOJ movement is impractical, and content produced by the movement can be found immediately and is present in greater quantity online. Observations will be conducted through examining social media platforms as they provide unfiltered and authentic rhetoric about the movement. Recently, more and more political movements have been driven by social media. The diversity of the internet allows users from across the political spectrum to present their beliefs to a broad audience, and organized groups such as the SOJ have increasingly utilized social media to demonstrate their views, making it an efficient area for data collection. 


\section{Population}

"Jefferson" consists of those residents who support the secession movement which encompasses 21 mostly rural Northern California counties, stretching from the Northern Central Valley to the Oregon border. The map below shows the region (Fox).

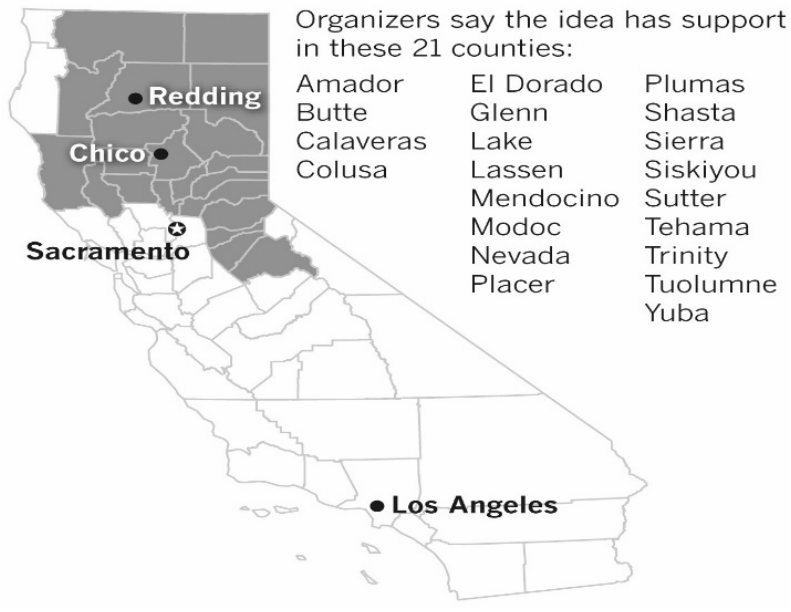

Figure 1. [Counties Supporting Jefferson Secession]

These counties have a combined population of 1.7 million people. The counties of Jefferson are predominantly non-Hispanic White, at $73 \%$, which is a vastly higher percentage compared to California, where non-Hispanic Whites make up 37\% of the rest of California (Menezes). The median household income in Jefferson is $\$ 57,000$ dollars, significantly less than the rest of California's $\$ 72,000$ dollar median income (Menezes). Sizable demographic differences may drive separatist movements, especially when these demographics affect social norms and regional identity. Economic differences also contribute to regionalism, as economically distinct regions demand greater autonomy, recognition, and political representation, all of which legitimize their ambitions for statehood.

\section{Sample}

A representative sample was collected and examined through Jeffersonian accounts on the social media platform Facebook to further investigate the movement's ideology and identity. Facebook was chosen because the majority of the content produced by the SOJ movement and its proponents is located here. Accounts containing "Jefferson" in their titles or possessing the seal of the SOJ as a heading and claiming to represent an organization or political party associated with the movement and supporting secession were considered for the sample. Accounts meeting the aforementioned criteria, but classified by Facebook as "groups" were disqualified due to lack of "official" messaging. Ten Facebook accounts qualified for examination in this study based on the prerequisite conditions. These Facebook accounts enabled examination of the rhetoric of the movement as a whole, rather than the opinions of individuals or non-Jeffersonian political groups that view the movement as an opportunity to advance special interests. Collecting data from social media and other online content is advantageous in that it allows the inclusion of larger sample sizes and is less time-consuming than interviews or surveys. Additionally, interviews and surveys may lead to bias or inaccuracies, as well as a small unrepresentative sample, whereas social media posts are unfiltered and may provide a more accurate representation of the views of the population. Data was collected from the following Facebook accounts: 
Jefferson State Independent Republicans

Political Party - Political Organization

https://m.facebook.com/Jefferson-State-Independent-Republicans-784423351892553/

Jefferson State Rising

Political Organization

https://www.facebook.com/Jefferson-State-Rising-103386517893079/

Jefferson State Tea Party

Political Organization

https://www.facebook.com/Jefferson-State-Tea-Party-805615206485773/

Jefferson Union National Party

@JeffersonUnionNationalPartyUSA - Political Organization

https://www.facebook.com/JeffersonUnionNationalPartyUSA/

Just Walk Away From California

@51stSOJ - Political Organization

https://www.facebook.com/51stSOJ/

Libertarian Party - State of Jefferson

@SoJ4liberty - Community

https://www.facebook.com/SoJ4Liberty/

SOJ51 News

@SOJ51News - Media/News Company

https://www.facebook.com/SOJ51News/

State of Jefferson

@StateOfJeffersonUSA - Nonprofit Organization

https://www.facebook.com/StateOfJeffersonUSA/

State of Jefferson

@StateofJeffersonXX - Public and Government Service

https://www.facebook.com/StateofJeffersonXX/

51 st State of Jefferson

@jeffersonstate51 - Political Organization

https://www.facebook.com/jeffersonstate51/

\section{Content Analysis (Quantitative/Qualitative)}

According to researchers Kim and Kuljis, "content analysis is a widely used research method for objective, systematic and quantitative examination of communication content" (369), and Snelson indicates that using qualitative content analysis is a useful tool for examining social media posts (1). This combination of quantitative and qualitative content analysis is critical to use when analyzing social media data, and in this study it provided an objective examination of social media content produced by the SOJ, providing insight into the sociopolitical, economic, and other regional 
elements that constitute Jeffersonian identity and ideology. For each of the "official" Facebook pages, posts ranging from January 1st, 2013 (the SOJ revival year) to April 1st, 2021 were examined. Each post was examined for words and phrases referring to factors that drive secession movements; Words referring to regional economic and sociopolitical issues such as "representation" and "taxation," along with words describing identity and ideology such as "conservative" and "rural" were collected and coded. These codes were then categorized in order to reveal foundational beliefs and points of identification for Jeffersonians. The categories were quantified using pie charts to reveal the frequency of views expressed, thus determining the pervasiveness of certain beliefs throughout the movement. Under the scope of framing theory, which claims that "media, as well as individuals, frame issues according to their own views and values" (M'Bareck 9), the posts in which these words were used were then further examined in order to demonstrate qualitative contextual statements reflecting Jeffersonian beliefs and markers of identification. Framing theory maintains that content on the official sites should reflect the identity and ideology of a movement. Therefore, a content analysis of the rhetoric displayed on the "official" SOJ social media accounts provides a valid and reliable representation of their identity and ideology.

\section{Materials/Instruments}

The search engine Google Chrome was used to browse SOJ Facebook accounts. Google Sheets was used to record, code and create tables to quantify the data. Atlas.ti was used to keep track of contextual information within posts.

\section{Procedure}

The social media accounts used in this sample were found via the Facebook search function using the terms "State of Jefferson," "State of Jefferson Movement," and "State of Jefferson California." The ten "official" accounts were selected based on the sample requirements. Every post from 2013 to 2021 was examined and coded in a Google sheet for its topic and message. The posts were coded using words and phrases that summarized their main ideas such as the political issue of "representation" and also those that described Jeffersonian identity such as "libertarian." These coded words were totaled and calculated into percentages, then organized into categories, based on the factors that drive secession movements. Coded words were used to create additional categories to reflect the descriptions of Jeffersonian identity and ideology. Statements about Jefferson were divided between ideological terms and descriptors of identity regarding the movement and its members, as well as the rural region itself. The coded words in these categories were quantified into five pie charts using Google Sheets.

\section{Results}

In total, 1,961 words were coded and were placed into the five categories: Rural Economic Issues, Socio-Political Issues, Political Leanings, Descriptions of the Movement and its Proponents, and Regional Identity. For rural economic issues, general taxation was the single largest concern of the Jeffersonians, making up 33.8 percent of the posts in this category. However, more rural-specific issues of water, fire, and gas taxes cumulatively formed 45.5 percent (see Figure 2) showing that while general taxation is a central concern, local economic issues are the largest priorities for Jeffersonians. The sociopolitical category showed that Representation and the Second Amendment at 36.9 percent and the latter at 43 percent, were the two largest areas of concern, and were individually larger than all other socio political categories combined (see Figure 3). The political leanings resulted in 26.2 percent of the posts being libertarian and 25.9 percent being anti-government (see Figure 4). Various conservative viewpoints made up 41.9 percent of the posts. Considering that opposition to government can be both a libertarian and conservative viewpoint, these results show that the political ideology of the movement contains mixed views. 
In describing the movement, the primary terms used were "underrepresented" and "liberty/freedom," which formed 41.1 percent and 36.2 percent of the posts (see Figure 5), indicating that these identifiers form an essential component of their identity. The regional identity category showed that 46.5 percent of posts focused on Jeffersonian rurality, while only 12.5 percent reflected the concept of the nationwide urban-rural divide (see Figure 6). Secessionism (22 percent), the history of the movement (12.5 percent), and Thomas Jefferson ( 6.5 percent) together formed 41 percent, demonstrating that they collectively are as important as rurality to the Jeffersonians, and therefore cannot be overlooked.

The qualitative component of this research reveals that Jeffersonians are highly skeptical of government, using anti-government and libertarian phrases like "Government isn't the solution, it's the problem." Although opposed to government control, they are also concerned about "underrepresentation" as an issue based on declining population: "our votes have been diluted 400\%," and as an uncomfortable experience of being left out: "That's why it feels like your vote doesn't count." Underrepresentation drives the effort to return political power to the region through the creation of a new state that will govern itself. The intention is that this governance will support and promote rural needs such as water and property rights and drought and fire protection while cutting taxes which are viewed as "the fines one pays for the crime of being useful and productive."

The emphasis on the rural nature of the region shows that Jeffersonians value rurality as a way of being that exists beyond the urban-rural divide. Inhabitants describe themselves and their region: "we have a different way of life," "we are farmers, ranchers, tradesmen," "these ruins of a gold rush town can only be found in the great State of Jefferson," and "the Jefferson way of life and our evergreen forests are far superior." Rural concerns and identity can be characterized as a modern variant of "Jeffersonianism," Thomas Jefferson's blueprint for society, which is defined in several Facebook pages as a belief in states' rights, local autonomy, self-determination and a strict interpretation of the Constitution. This strict interpretation is also displayed by their overwhelming support for the Second Amendment. Frequently seen throughout the FB pages is the slogan "To Keep and Bear" and the rhetoric revealed a concern about self-protection that, given the remote locations of many inhabitants, may be reasonable. Jeffersonians' perspective is: "disarming innocent people does not protect innocent people" and "police have no duty to protect you."

In the "fight" for secession, the Jeffersonians are prepared to defend their "freedom" and "liberty," but they are also "patriotic" in that they are not seeking to secede from the United States, but seeking to form a new state. Their identification with secessionism is manifested in many references to the storied history and cultural heritage of the past secession movement in the form of continual re-posting of old newspaper clippings and photos that motivate and inspire the current secessionists whose identity reflects the nature of the region in which they reside. This research has provided a description and quantification of the ideology of the movement that was previously absent. The movement is driven by agrarianism, possesses conservative, yet libertarian values, and espouses an ideology of Jeffersonianism reflected in the name of the state. While remaining closely tied to their ideology, Jeffersonian self-identification is also rooted in the rural nature of the region in which they reside. 
100

75

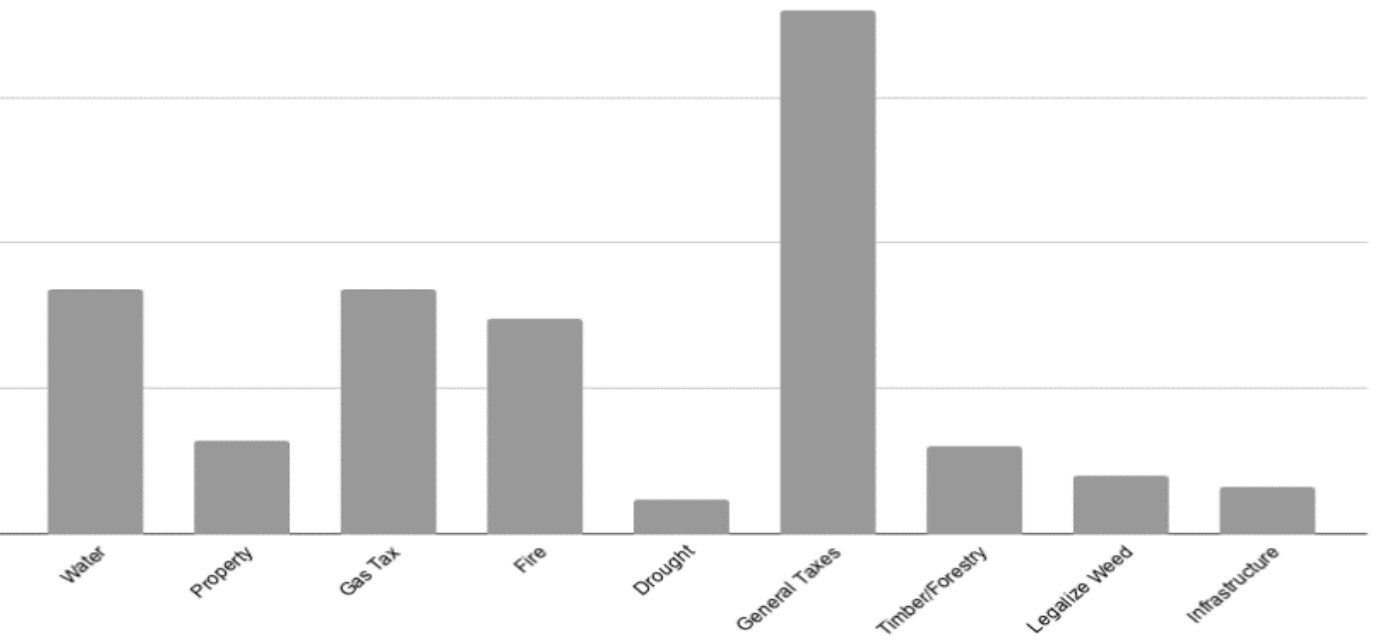

Figure 2. Jefferson Secession - Rural Economic Issues

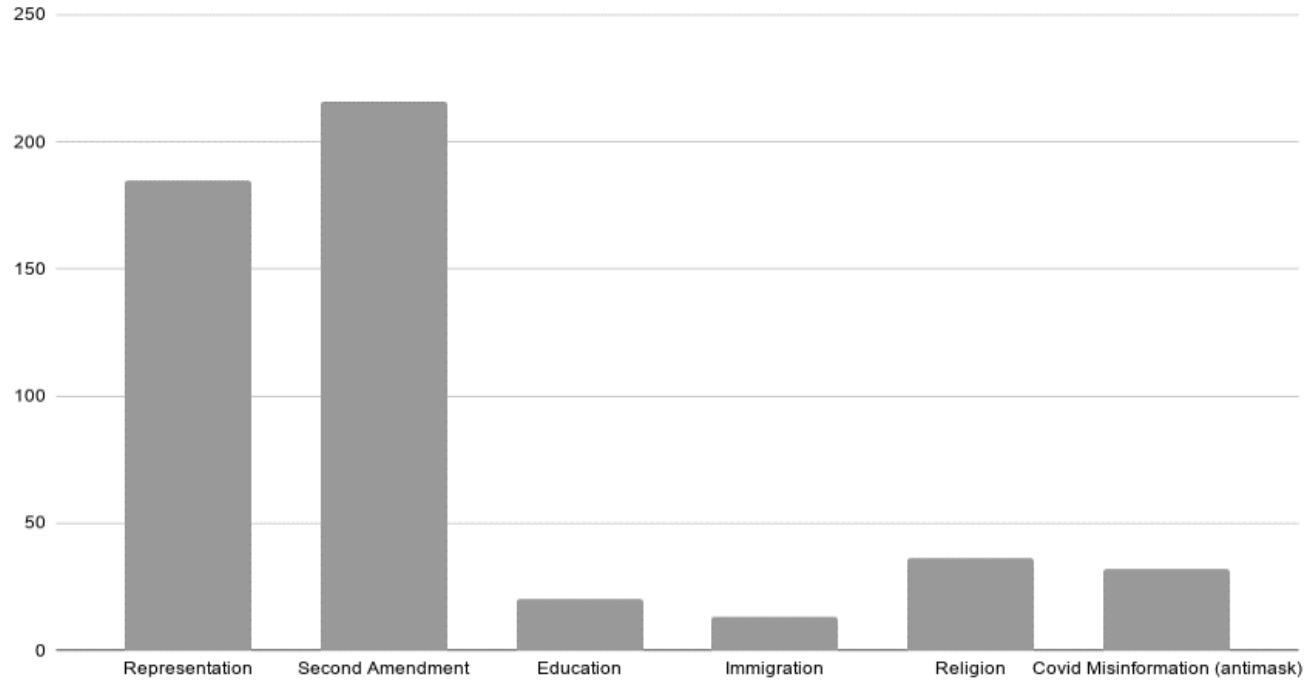

Figure 3. Jefferson Secession - Sociopolitical Issues 
100

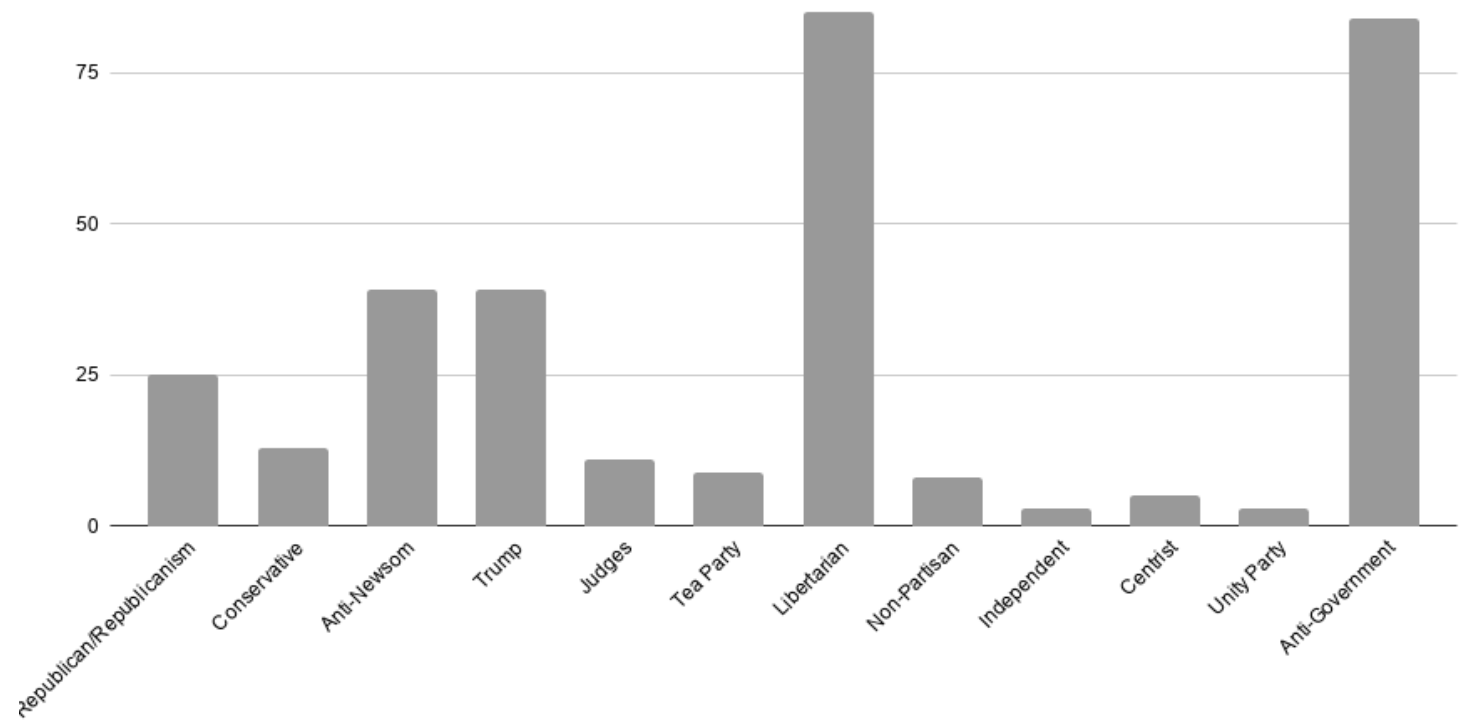

Figure 4. Jefferson Secession - Political Leanings

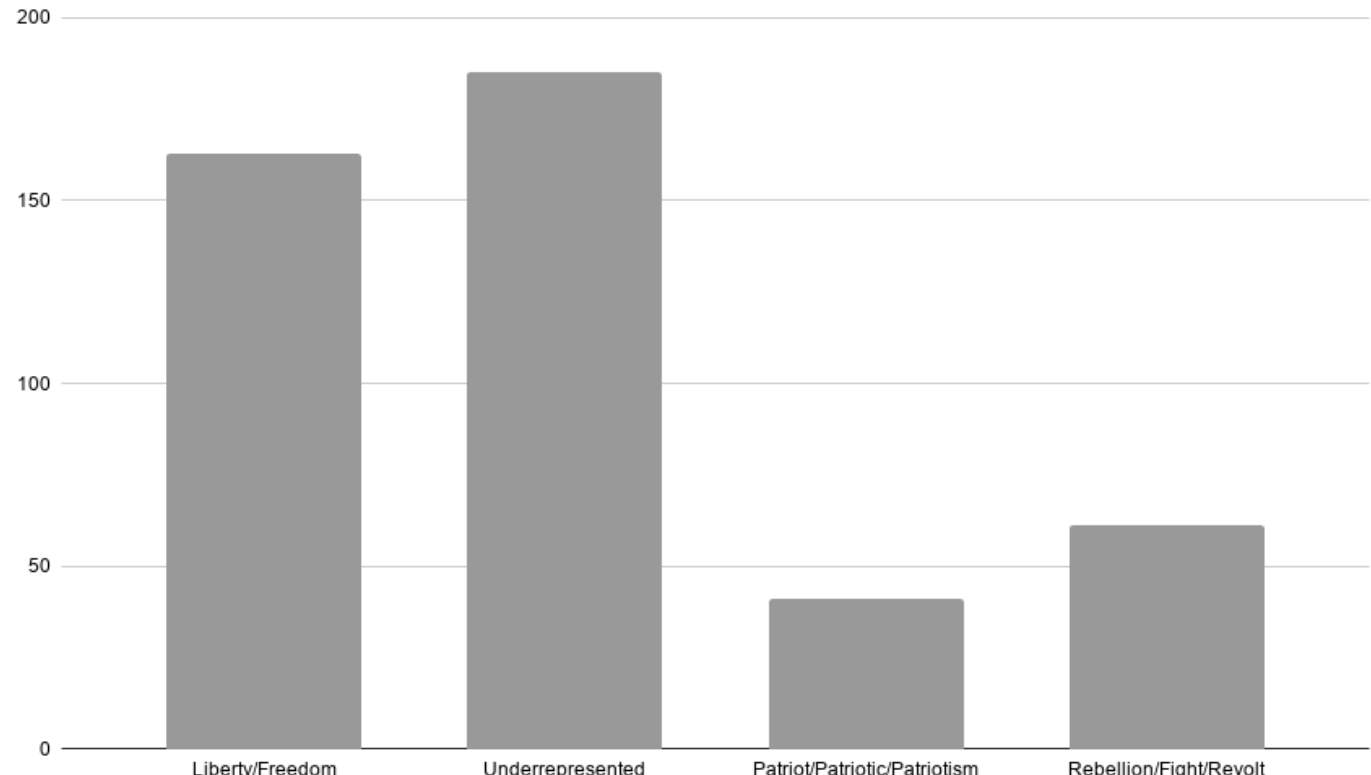

Figure 5. Jefferson Secession - Descriptors of the Movement and its Proponents 


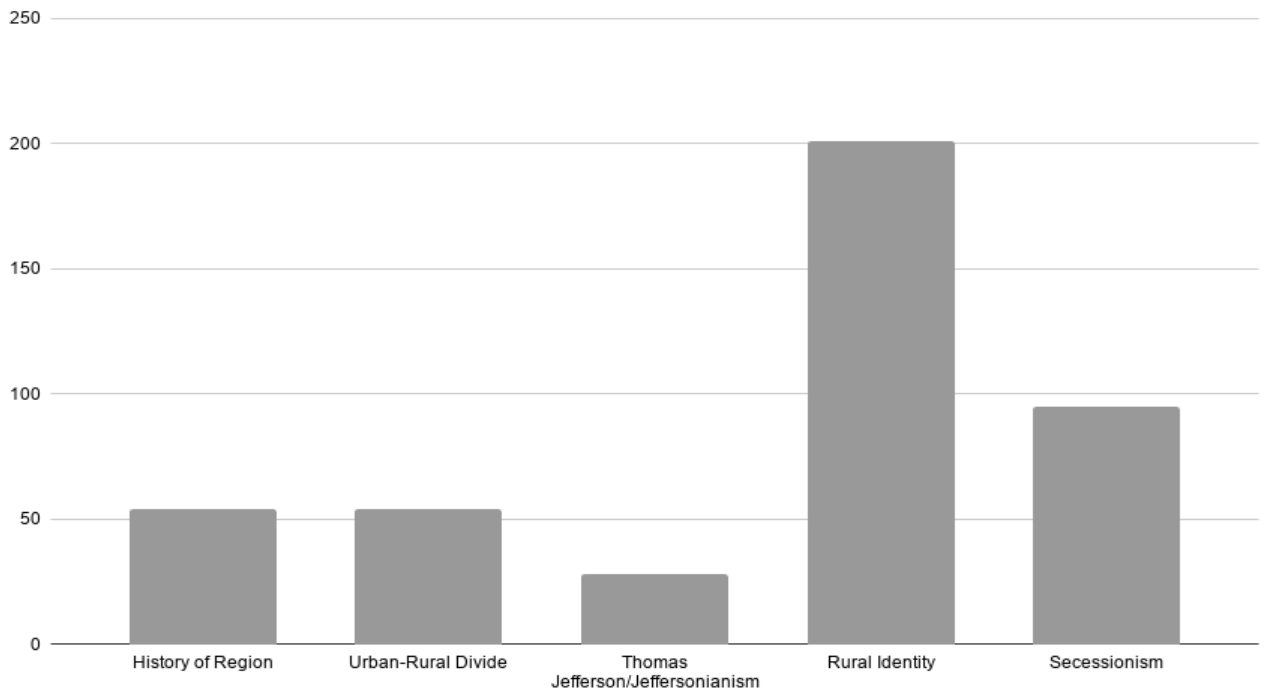

Figure 6. Jefferson Secession - Regional Identity

\section{Limitations}

There are several limitations to this research including time-frame, sample, and potential bias. This research study was conducted over an eight-month period that limited the amount of data that could be collected and analyzed. Additionally, over time, posts may be changed or deleted, leading to difficulties with replication.

Although this case study provides an in-depth investigation into a group of people, the small sample size limits generalization to the larger population being studied and application to other settings. Furthermore, because the sample was chosen based on predetermined requirements, there is a chance that sampling bias resulted in the chosen Facebook pages not reflecting the characteristics of the target populations.

It is also necessary to consider researcher and participant bias. When conducting a content analysis, beliefs of the researcher may influence the interpretation of the data. Furthermore, content posted online is subject to the bias of individuals or groups and may not represent views of the larger population. For example, significantly more posts from Libertarian groups existed, resulting in Libertarian issues being more prevalent within the results. However, the rationale for conducting a content analysis in this study operated under the framing theory, which maintains that "media, as well as individuals, frame issues according to their own views and values" (M'Bareck 9) and therefore supports the understanding that official sites selected for the sample should reflect the views of the larger population being studied.

\section{Discussion/Significance}

The State of Jefferson remains an obscure movement for most scholars. While there was previously an absence of data regarding the nature of the movement, this research provides some understanding of what it stands for on a number of issues. Jefferson scholar Peter Laufer stated that Jefferson "can be considered. . . a metaphor for the kinds of problems we see nationally," (Breaking up is Hard to Do) and the movement does focus heavily on issues that are present for rural Americans nationwide, like gun rights and taxation. However, Laufer's assertion that it "boils down more or less to a rural-urban divide" fails to capture the entire nature of the movement, as this research found that rural identity as an independent concept is a stronger point of self-identification for Jeffersonians than simply rural in opposition to urban. The Jefferson movement is driven by trends similar to other separatist movements. For example, Cunningham 
found that groups that are excluded from power are more willing to resort to "irregular strategies" to help themselves (292), and the State of Jefferson movement reflects this observation, with its heavy emphasis on underrepresentation. Additionally, economic hardship and frustration combined with a persistent regional identity have been factors noted in secessionist movements over time (Muñoz and Tormos 24) and Jeffersonian concerns about taxes and strong rural regional identity are major elements of this movement. Although rural areas retain disproportionate political power on the national level, on the statewide level they are being drowned out by urbanization. Understanding the causes and nature of the movement may help to identify parallel conflicts within other U.S. states. Recognizing the specific issues that aggrieve rural areas may allow groups in power to consider decisions they could make to address the needs of rural Americans and limit the growth of secessionist movements. This exploration of the SOJ has quantified the identity and ideology of the movement. However, with such a diverse movement, it is necessary to conduct further research into Jefferson, to discover events that most contribute to secessionism. Jefferson moves from times of neardormancy to periods of heightened activity, and examination of outside factors that cause the movement to disappear and reappear would greatly improve scholarly understanding. Additionally, an examination of prior resolutions to separatist conflicts is needed, as Jefferson seems to have no end in sight.

\section{Acknowledgments}

I would like to thank my AP Capstone Research instructor, Mrs. Maura Large for her patience and guidance, my expert advisor, Mr. Pete Nordlund for his significant contributions to my understanding of Jeffersonianism, and my family for their boundless support.

\section{Works Cited}

Accordino, John. "Introduction to Bridging the 'Urban-Rural Divide." State and Local Government Review, vol. 51, no. 4, Dec. 2019, pp. 217-222, doi:10.1177/0160323X20932624.

Armus, Teo. "Mississippi Republican Calls for His State to 'Succeed from the Union' after Biden Victory." Washington Post, 11 Nov. 2020, www.washingtonpost.com/nation/2020/11/11/mississippi-secede-electionrepublican $/ \% 3$ foutputType=amp.

Boyle, Katharine, and Pierre Englebert. "The Primacy of Politics in Separatist Dynamics.” Cega.berkeley.edu,2006, cega.berkeley.edu/assets/miscellaneous_files/wgape/10_Englebert.pdf.

Braizat, Fares. Arab Center for Research \& Policy Studies, 2011, Sudanese Public Opinion after Secession, pp. 126. www.jstor.org/stable/resrep12702.

Branson-Potts, Hailey. "In California's Rural, Conservative North, There Are Big Dreams for Cleaving the State." The Los Angeles Times, 17 Mar. 2018, www.latimes.com/local/lanow/la-me-ln-state-of-jefferson-activists20180317-htmlstory.html.

" "Breaking Up Is Hard to Do: A History of State Secession."” All Things Considered, created by Audie Cornish, and Melissa Block, 6 Nov. 2013, www.npr.org/templates/story/story.php?storyId=243537886.

Buckholz, Quentin. “The Dogs That Didn’t Bark: Elite Preferences and the Failure of Separatism in Kharkiv and Dnipropetrovsk." Problems of Post-Communism, vol. 66, no. 3, May 2019, pp. 151-160. EBSCOhost, doi:10.1080/10758216.2017.1367256. 
Cunningham, Kathleen Gallagher. "Understanding Strategic Choice.” Journal of Peace Research, vol. 50, no. 3, 2013, pp. 291-304., doi:10.1177/0022343313475467.

Davis, W. N. "State of Jefferson.” California Historical Society Quarterly, vol. 31, no. 2, 1952, pp. $125-138$. JSTOR, doi:10.2307/25156352.

Derrick, Matthew A. "The State of Jefferson: Beyond Myth and Mindset, Toward Enhanced Conceptualization of a Region.” Humboldt Journal of Social Relations, vol. 36, 2014, pp. 4-16. JSTOR, www.jstor.org/stable/humjsocrel.36.4.

DeWolf, Bill. “Jefferson State of Mind.” Trinity Journal, 7 Feb. 2018, www.trinityjournal.com/community/columnists/article_97b7c112-0ba1-11e8-8c97-f3d60e13c76e.html.

Fox, Joe. [Counties Supporting Jefferson Secession], "The Jefferson Census: Who Lives in the Northern California Area Lobbying to Form America's 51st State?" State of Jefferson Formation Committee, Map. Latimes.com, 17 Mar. 2018, www.latimes.com/projects/la-me-the-jefferson-census/.

Fox, Nicholas. "New State Movements, 1900-2013.” Humboldt Journal of Social Relations, vol. 36, 2014, pp. 185186. JSTOR, www.jstor.org/stable/humjsocrel.36.185.

Guibernau, Montserrat. "National Identity, Devolution and Secession in Canada, Britain and Spain." Nations \& Nationalism, vol. 12, no. 1, Jan. 2006, pp. 51-76. EBSCOhost, doi:10.1111/j.1469-8129.2005.00230.x.

Hagendoorn, Louk, et al. "Support for Separatism in Ethnic Republics of the Russian Federation." Europe-Asia Studies, vol. 60, no. 3, 2008, pp. 353-373. JSTOR, www.jstor.org/stable/20451506. Accessed 14 Dec. 2020.

Ker-Lindsay, James. "Great Powers, Counter Secession, and Non-Recognition: Britain and the 1983 Unilateral Declaration of Independence of the 'Turkish Republic of Northern Cyprus.'” Diplomacy \& Statecraft, vol. 28, no. 3, July 2017, p. 431. EBSCOhost, doi:10.1080/09592296.2017.1347445.

Kim, Inhwa, and Jasna Kuljis. “Applying Content Analysis to Web-Based Content.” Journal of Computing and Information Technology, vol. 18, no. 4, 2010, p. 369., doi:10.2498/cit.1001924.

Koubi, Vally, and Tobias Böhmelt. "Grievances, Economic Wealth, and Civil Conflict.” Journal of Peace Research, vol. 51, no. 1, 2013, pp. 19-33., doi:10.1177/0022343313500501.

Lalande, Jeff. “"The State of Jefferson': A Disaffected Region's 160-Year Search for Identity.” Oregon Historical Quarterly, vol. 118, no. 1, 2017, pp. 14-41. JSTOR, doi:10.5403/oregonhistq.118.1.0014.

Laufer, Peter. The Elusive State of Jefferson: a Personal Journey through the 51st State. TwoDot, an Imprint of Globe Pequot Press, 2013.

Laufer, Peter. “All We Ask Is To Be Left Alone.” Humboldt Journal of Social Relations, vol. 36, 2014, pp. 17-33. JSTOR, www.jstor.org/stable/humjsocrel.36.17.

Macculloch, Robert, and Silvia Pezzini. "The Roles of Freedom, Growth, and Religion in the Taste for Revolution." The Journal of Law \& Economics, vol. 53, no. 2, 2010, pp. 329-358. JSTOR, doi:10.1086/605093. 
M'Bareck, Mohamed Lemine, "Political Speech on Twitter: A Sentiment Analysis of Tweets and News Coverage of Local Gun Policy"(2019). Theses and Dissertations. 3157.https://scholarworks.uark.edu/etd/3157

McKee, Guian. “UVAToday.” News.virginia.edu, news.virginia.edu/content/what-2020-election-results-tell-usabout-americas-growing-urban-rural-divide.

Menezes, Ryan. "The Jefferson Census: Who Lives in the Northern California Area Lobbying to Form America's 51st State?" Latimes.com, 17 Mar. 2018, www.latimes.com/projects/la-me-the-jefferson-census/.

Michel, Casey. "When Oregon Ranchers Tried to Start Their Own State.” Politico Magazine, 11 Jan. 2016, www.politico.com/magazine/story/2016/01/oregon-rebellion-jefferson-state-213520.

Miley, Thomas Jeffrey, and Roberto Garvía. "Conflict in Catalonia: A Sociological Approximation.” Genealogy, vol. 3, no. 4, 2019, p. 56., doi:10.3390/genealogy3040056.

Muñoz, Jordi, and Raül Tormos. "Economic Expectations and Support for Secession in Catalonia: between Causality and Rationalization." European Political Science Review, vol. 7, no. 2, 2014, pp. 315-341., doi:10.1017/s1755773914000174.

Olomojobi, Yinka, and Omoigerale Omonye. "Contested Sovereignty and Conflict: Between Spain and Catalonia." Russian Law Journal, vol. 7, no. 1, 2019, pp. 138-153., doi:10.17589/2309-8678-2019-7-1-138-153.

Parker, Kim, et al. "Similarities and Differences between Urban, Suburban and Rural Communities in America." Pew Research Center's Social \& Demographic Trends Project, 22 May 2018, www.pewsocialtrends.org/2018/05/22/what-unites-and-divides-urban-suburban-and-rural-communities/.

Shulman, Alayna. "Welcome to 'State of Jefferson': Alternate 'Calexit'." Redding Record Searchlight, 12 Jan. 2017,www.redding.com/story/news/local/2017/01/12/welcome-state-jefferson-alternate-calexit-trump /96376810/.

Snelson, Chareen L. "Qualitative and Mixed Methods Social Media Research: A Review of the Literature." International Journal of Qualitative Methods, Dec. 2016, doi:10.1177/1609406915624574.

“State of Jefferson.” Jefferson Public Radio, Southern Oregon University, www.ijpr.org/state-of-jefferson.

Torcal, Mariano, and Fabiola Mota. “The Role of Political Parties in Shaping Citizens' Political Preferences for the Territorial Organization of the State: the Spanish Case.” European Political Science Review, vol. 6, no. 3, 2013 , pp. 477-502., doi:10.1017/s1755773913000210.

"Unemployment in the Los Angeles Area by County - May 2016 : Western Information Office." U.S. Bureau of Labor Statistics, U.S. Bureau of Labor Statistics, 26 July 2016, www.bls.gov/regions/west/newsrelease/unemployment_losangeles.htm.

Wood, John R. "Secession: A Comparative Analytical Framework." Canadian Journal of Political Science / Revue Canadienne De Science Politique, vol. 14, no. 1, 1981, pp. 107-134. JSTOR, www.jstor.org/stable/3230396. 